\title{
"Our Native Clay": Racial and Sexual Identity and the Making of Americans in The Bridge
}

JARED GARDNER

Johns Hopkins University

Being a naïve European, I could not help remarking to my American companion: "I really had no idea there was such an amazing amount of Indian blood in your people."

"What!" said he. "Indian blood? I bet there is not one drop of it in this whole crowd. ..."

I know the mother nations of North America pretty well, but if I relied solely on the theory of heredity, I should be completely at a loss to explain how the Americans descending from European stock have arrived at their striking peculiarities.

-Carl Jung, "Your Negroid and Indian Behavior" (1930)

In his letters, Hart Crane consistently aligned The Bridge (1930) with the cultural project of defining America's identity in the 1920 s. From his earliest theorizing on his poem in 1923, Crane imagined its focus in these terms: "The initial impulses of 'our people' will have to be gathered up toward the climax of the bridge, symbol of our constructive future, our unique identity." 2 Although he offered notoriously conflicting assertions about his poem over the next seven years, Crane maintained his motivating interest in the discovery of such an identity. As he told his patron, Otto Khan, he desired "to enunciate a new cultural synthesis of values in terms of our America" (L, 223) out of the "organic and active factors in the experience and perceptions

Jared Gardner is a graduate student in the English Department at Johns Hopkins University. He is currently working on his dissertation entitled "Gothic Nation: The Exploration of American Race, 1797-1838."

American Quarterly, Vol. 44, No. 1 (March 1992) (C) 1992 American Studies Association 
of our common race, time and belief" ( $\mathrm{L}, 261)$. One of the "startling discoveries" he made during this search for "our common race" was "the currency of the Indian symbolism in whatever is most real in our little native culture, its persistence, despite our really slight contact with that race . . . cropping out in the most unexpected places." 3

Crane's discovery of the Indian's centrality to American identity was not original to his work. Many writers at the time were attempting to define an American identity with the Indian as a central symbol. America after World War I was now prepared to define a native genealogy distinct from that of Europe. With the nation's creation myths up for grabs, writers such as William Carlos Williams and Waldo Frank created field guides to this incipient culture, pointing away from what seemed to them to be false Old World inheritance and towards the Indian as the potential of the nation. As Frank writes in The Rediscovery of America (1929), "our root is in the red men; and our denial of this is a disease within us." 4 Not simply a literary conceit, however, this formulation of the Indian's relation to American identity was one aspect of a social project that sought to claim an inheritance for America that would distinguish it wholly from its European parents.

This version of the making of Americans in the 1920s involved this imagining of a race without blood, defining a people without reference to its biological inheritance, so that, by 1930, it was possible for Jung to conceive of America as a nation of Indians. While lineally the claim is illogical, as Jung's interlocutor argues, it becomes useful in the 1920 s precisely because no Indian blood was involved. Attempting to theorize this formula, Jung describes the American as unique because of his absorption of primitive behaviors: "the spirit of the Indian gets at the American within and without." 5 As this inheritance was theorized by writers in the 1920 s, the cultural embrace of the Indian allows for the rejection of Old World genealogy in favor of a new kind of inheritance, an American self. As we shall see, it is this self-justifying contradiction, divorcing the claim to racial identity from biological inheritance, that makes Crane's myth possible.

Crane's appropriation of the Indian in the formulation of American identity offered by The Bridge is unique in what I shall argue is the identification of the nation's Indian inheritance with a myth of homosexual origins. At the time, this identification would have seemed profoundly counterintuitive. Along with the racial and ethnic groups excluded from the model of citizenship in the 1920s, homosexuals 
were also explicitly proscribed from the construction of citizenship. Crane's The Bridge, however, provides a comprehensive allegory of the making of the new American identity, one that, in bridging the theoretical leap that the new formulation of citizenship required, would work to imagine Crane's own sexuality as neither an oppositional nor marginal identity, but as the very definition of the American citizen itself. Although we might today take for granted a certain kind of ideological claim on the Indian by white America, it is important to understand the particular value and demands placed on the 1920s' association. For it is these terms that at once seem to preclude Crane's identification of the homosexual with the Indian, while at the same time empowering the poem's claim for the homosexual as the pure American. ${ }^{6}$

In "The Dance," which Crane referred to as "the basic center and antecedent of all motion" ( $\mathrm{L}, 271)$ of The Bridge, he rewrites one of America's founding myths, the Pocahontas story, editing out aspects of the tale that were troubling to the 1920 s' imagination by transforming the miscegenist story into a homosexual myth. Instead of offering herself to the white man, Pocahontas here acts as mediator between white and red man. It is in this union, through the bridge of the female body of Pocahontas, that our America is born. By grounding the identification between Indian chief and white poet in the nonbiological terms that constructions of citizenship in the 1920s made conceivable, the genealogy which Crane reenacts for us in the poem, and through which we are asked to trace our cultural identity, comes to have its inception in the union of two men.

As Crane wrote to Khan in 1927,

Not only do I describe the conflict between the two races in this dance-I also become identified with the Indian and his world before it is over, which is the only method possible of ever really possessing the Indian and his world as a cultural factor. I think I really succeed in getting under the skin of this glorious and dying animal, in terms of expression, in symbols, which he himself would comprehend. (L, 307)

For Crane, possessing the Indian as a "cultural factor" becomes a homosexual project; as the poem would have it, only the homosexual can claim a genealogy without biology, and only such a genealogy can truly evade all the complications of race. America's identification with the Indian in the 1920s allowed for the formulation of a national self 
that is at once inherited while also remaining defensible against biological claims to inclusion on the part of immigrant populations. Crane's identification of the Indian with the homosexual, an identity excluded from this inheritance, allows him to rewrite himself as founding father.

The first readers of The Bridge overwhelmingly judged it an ambitious "failure," and one of the primary grounds for this critique was the poem's thematic reliance upon extrinsic cultural texts. ${ }^{7}$ Much of the later criticism has either followed the New Critics in rejecting the poem's reliance on an external logic, or else has argued that the poem has no interest in history at all. ${ }^{8}$ These critical negations of the poem's self-avowed engagement with American culture operate out of the assumption that the poem is a search for poetic identity, relegating concerns central to the poem, such as racial, sexual, and national identity, to extratextual thematic consideration. The criticism has failed to recognize the extremely complex and often troubling levels on which Crane is confronting these issues in his attempt to claim a historical place for the homosexual by inventing a nativist history purified through a marriage between white man and Indian.

The poem's understanding of America demands to be read in relation to specific formulations - literary, political, and popular-of national identity in the 1920s. In order to recover the logic through which The Bridge engages American citizenship, two developments that established its terms must first be explored: the energetic recruitment of American Indians and the simultaneous campaign to expel homosexuals from the armed forces in World War I-events focused around two of the poem's central concerns, national and sexual identity, and involving two of its leading actors, the Indian and the sailor. In examining how Crane uses the Indian and the sailor in order to Americanize the homosexual, we shall see how these two apparently opposed identities are brought together (as indeed they also were in Crane's sexual relationships with Indians and sailors) to prove them mutually inextricable in the formulation of an American race.

* * *

During World War I, American Indians, most of whom were not yet citizens, were enlisted in unprecedented numbers and "in far greater percentages than their total population warranted." One motivation fueling this drive (one that was not directed to any other ethnic group) 
was a desire to define Americans returning to Europe as a race apart from the countries from which they were biologically descended. In several important ways, World War I marks the fulcrum in the transition from Progressivist assimilationism to 1920 s nativism. ${ }^{10}$ And it is at this point that the Indian is transformed from a target of assimilationist policies to a model of an American identity unacquirable through assimilation. $^{11}$

The Indian soldier was an ideological focal point for the battle between proponents of the melting pot and the emerging commitment to a unique American cultural identity. The debate focused on whether these new soldiers should be assimilated into regular troops, as Cato Sells, Commissioner of Indian Affairs insisted, or should be placed instead in segregated units, as Edward Ayer of the Board of Indian Commissioners would have had it. ${ }^{12}$ In an article entitled, "The "First Americans' as Loyal Citizens," Sells imagines the war as a grand Americanization program in which the Indian would fight "side by side with the white man, not as Indians but as Americans . . gaining by contact an education that will lead them away from the tribal relations, and give them a definite comprehension of the genius of American institutions." The war for Sells is the ultimate civics course, offering "the beginning of the end of the Indian problem." 13

For those who argued for the unique symbolic function of the allIndian troop, however, the "vanishing" Indian represented resistance to the melting pot that had failed to produce a unified America. The Indian, brought back to the Old World as the unique mark of the American, defined patriotism as the defense against a mixed European identity. The all-Indian troop would encourage the national self-identification that patriotism required. As Dr. Joseph Dixon defended Ayer's plan before Congress:

The establishment of purely Indian units would . . . have a psychological effect upon the entire country. The enlistment of purely Indian units would fire the enthusiasm and arouse the patriotism of the entire country. ${ }^{14}$

The Indian soldier defined the army in opposition to the nations from which Americans descended, and so would "arouse the patriotism of the entire country" by symbolizing freedom from European inheritance. As a wartime review of a collection of "American Indian Poetry" defines the "real American classic," "none of it has any trace of European influence." 15 And as Coolidge's campaign in Indian head- 
dress made a spectacle of this process, the donning of the red mask cleanses the American of European racial marks. The Indian enlistment effort imagined that the American was an Indian (not a European), and the legislative process ending in 1924 made certain that the Indian was now an American, closing off access to American identity in the postwar decade. Reviewing the Indian's effort at the war's end, Ayer could write, "Not only were the Indians the first Americans, but they are the first and last Americans as was proved by their record in the World War." 16

As John Higham and others have demonstrated, by World War I, it was perceived by many in the government and media that the melting pot had failed. The war became, for writers in the twenties, the event which rescued the nation by revealing how fully the ethnic populations had preserved their racial allegiances. ${ }^{17}$ Commending the Immigration Act in 1924, Robert DeC. Ward writes,

During the years of the war various alien racial groups in the country showed clearly enough that their sympathies were not American but European. European antagonisms, bred and nourished through centuries abroad, came to the surface in the United States. Those who had been relying on the Melting Pot to accomplish assimilation realized that they had cherished false hopes. The statistics of the Draft threw a great deal of light upon the whole problem of the foreign-born in the United States . . . [The Johnson Immigration Act] is an emphatic national decision that, to quote President Coolidge, "America must be kept American." It is based on bedrock principles. It marks a turning point in American civilization. ${ }^{18}$

In Lothrop Stoddard's terms, "the late war . . . must bring home the truth that the basic factor in human affairs is not politics, but race." 19 For these writers and the Americans whose anxieties they voiced, the war had shown that a political solution to the preservation of American identity was not adequate; supposedly naturalized immigrants were revealed to be indelibly marked by race as inferior soldiers, cowards, and traitors. And the Indian was now discovered to be the truest patriot; the war revealed that many ethnic groups had maintained strong bonds to Europe while the Indian remained true only to his native land. As the Committee on Public Information lauded the 1918 film, The American Indian Gets into the War, because it "shamed the white man into a higher patriotism," ${ }^{20}$ so the Indian soldier, "most forward among the people of America in volunteering for military service," 21 defined 
patriotism in an ethnically divided America by offering a native culture which could be claimed without blood descent.

The defining of a national identity to be protected from biology required determining what it was that made the American and identifying those who must be barred from access to that claim. Reading two pieces of legislation of 1924, the Johnson Immigration Act (severely curtailing entrance to America) and the Citizenship Act (making Indians Americans), Walter Benn Michaels has demonstrated how both worked to close off access to and reconstitute citizenship by instituting a notion of culture as that which is held in common by both Indian and American while remaining unattainable to alien populations. The acts defined American citizenship in terms that escaped the necessarily problematic notion of a native identity based wholly on either biology or a technology of instruction; Michaels writes,

If . . a as an inheritance, culture is unlike the citizenship of the melting-pot because it cannot simply be achieved, it is also unlike race and environment in that it cannot simply be inherited. The distinctive mark of culture is that it must be both achieved and inherited. ${ }^{22}$

Claiming nonbiological inheritance from Indians as the mark of the American allowed for a bulwark against assimilation that retained the force of nativist rhetoric without the complications of a defense grounded wholly on race. Only Americans have claim to the Indian, and this inheritance must be actively protected. Like Coolidge's campaign for the protection of American identity through education in the classics, Indian culture, as America's native "classical" inheritance, comes to function as the nation's unique birthright.

Fighting like Indians, then, not in defense of blood but of cultural inheritance, becomes an alternative to the assimilative process. In his poem, "Our Mother Pocahontas" (1917), Vachel Lindsay describes how the embrace of the nonbiological mother, the Indian, allows those who fought the war to escape their racial inheritances and to become finally and fully American. "John Rolfe is not our ancestor. / We rise from out the soul of her." Through the embrace of Pocahontas, we reject biological descendence from Europe (Rolfe) in favor of a spiritual inheritance ("from out the soul") transmitted through the Indian. 
Come roaring in. The newest race

Is born of her resilient grace.

We here renounce our Teuton pride:

Our Norse and Slavic boasts have died:

Italian dreams are swept away,

And Celtic feuds are lost today ... .

She sings of lilacs, maples, wheat,

Her own soil sings beneath her feet,

Of springtime

And Virginia,

Our Mother, Pocahontas. ${ }^{23}$

Lindsay's poem, entrenched between the rhetoric of the Progressive Era and the anxieties of the 1920s, provides a crucial set of terms for understanding the appropriation of the Indian in the defining of American citizenship during and after the war. In classic Progressivist terms, the war figures as an assimilating institution through which immigrant groups renounce their native cultures for an American identity, but in employing the Indian as the bridge to Americanization, Lindsay moves away from the old formulation of this transmission as fundamentally political and towards an understanding of American identity as a spiritual inheritance. We are born of "our mother" not through biology, but "of her resilient grace," "from out the soul of her" (emphases added). And the war which grants those who fight access to this nonbiological genealogy is also that which closes off access to an American identity to those who follow. In Lindsay's terms, those who fought in the war (and fought like Indians) could now be Americans; those who did not would never escape their "racial marks" ${ }^{24}$ and thus could never be Americanized.

$$
* \quad * \quad *
$$

The emergence of a national identity defined by the Indian soldier arises concomitantly with the invention and exposure of the homosexual threat to that identity. ${ }^{25}$ It was important that an allegedly vanishing population such as the Indians could come, through their recruitment into the army, to function as model citizens who evaded the complications of biology ${ }^{26}$ At the same time, however, another nonprocreative population was in the very process of appearing during the war: homosexuals were entering public discourse. And where the Indian could represent a unique native inheritance, the homosexual could stand for 
Old World decadence, moral degeneracy, and an imagined threat to the heterosexual models upon which Big Business would increasingly depend. ${ }^{27}$ As a doubled and inverted model of the Indian's nonbiological relation to American identity, and through the same set of terms whereby the Indian became the model for citizenship, the homosexual came to be the model for decitizenship.

In the early 1920s, the construction of homosexuality moved beyond the scientific discourse which had invented it. The war was a primary site of the dissemination of consciousness about homosexuality, and contributing dramatically was the scandal surrounding Franklin Delano Roosevelt's vice squad operations at the Newport naval training base, which its historian, Lawrence Murphy, has described as "the most extensive systematic persecution of gays in American history." 28

As Assistant Secretary of the Navy, responding to complaints of widespread homosexuality at Newport and to Secretary Josephus Daniels's demand for " a wholesome atmosphere for young men training in the navy," ${ }^{29}$ Roosevelt authorized an independent effort to expose and expel the homosexual. His vice squad agents operated by gaining the confidence of suspects and engaging them in sexual acts for the purposes of entrapment. Roosevelt, "eager for the protection of . . . young men from such contaminating influences," 30 encouraged this internal operation (though he later denied knowledge of its methods), and the squad expanded its focus to civilians. The arrest of a prominent local clergyman brought the scandal into the headlines and before a federal court in 1920, eventuating in a full congressional investigation.

The source of the outrage against the operation was that good sailors were being forced to commit immoral acts by the navy; in the words of one editor, they were "made perverts by official order." ${ }^{31}$ As the New York Times responded to the release of the committee's report in 1921 ,

most of the details of the scandal, as disclosed in the investigation, are of an unprintable nature. The committee finds its basis for its criticism of $\mathrm{Mr}$. Daniels and Mr. Roosevelt in the charge that with their knowledge enlisted men of the navy were used as participants in immoral practices for the purpose of obtaining evidence on which to dismiss offenders from the navy. Such use of enlisted men under orders or suggestions of superior officers, the report declares, "violated the code of the American citizen and ignored the rights of every American boy who enlisted in the Navy to fight for his country. ${ }^{32}$ 
Roosevelt came to be held responsible for the very thing he had sought to prevent: the homosexualization of the U.S. Navy. The scandal unfolded into Roosevelt's early political career, and as the papers followed investigations into the operation over the next year, many learned for the first time of the existence of a homosexual community in America. ${ }^{33}$

The operation at Newport was part of a widespread effort to expunge homosexuality from the military, and from the terms being used to define the American citizen. ${ }^{34}$ Where the Indian comes to define American citizenship through fighting in the war, the exclusion of the homosexual from military service made him the paradigm for decitizenship. But Roosevelt's vice squad served in the public imagination as itself a recruitment device for homosexuality, producing homosexuals where it had sought to eliminate them. The attempt to bracket deviant sexuality from the definition of the American served instead to educate the nation with "the first detailed documentary evidence in America of a distinctive homosexual community." 35

The recruitment of the Indian provided a model of citizenship which encouraged an understanding of culture based on a genealogical transmission that had to be simultaneously inherited (by Americans) and actively embraced (by fighting to defend that inheritance). At the same time it became necessary to exclude the homosexual who complicated the claims to such an identity by engaging similarly nonprocreative terms of relation and community. As we shall see in discussing the ways in which these two doubled and inverted narratives are negotiated in The Bridge, the specter raised by the deviant sailor was the way in which this new model of citizenship, based on a notion of an inheritable culture, described a theory of genealogy that was compatible with homosexuality. In articulating a theoretical correspondence between homosexuality and models of American cultural purity, Crane redefines the homosexual, not as a threat to this new model but as its exemplary citizen.

* * *

In his first book of lyrics, White Buildings (1926), Crane worked through a highly compacted poetic to discover a new vocabulary for his sexuality, developing what John Irwin calls "progressively more complex names for love." 36 In The Bridge, Crane puts this poetic to work in writing a version of America's history and traditions. In doing 
so, he attempts to inscribe his sexuality as the correct reading of the myths that define American culture, myths whose supposed misinterpretations have led to the degradation of modern society. The Pocahontas myth provides the central site of this effort.

Philip Young writes, "Pocahontas is one of our few, true native myths . . . and [is] offered as a magical and moving explanation of our national origins." 37 This myth has been the hunting ground for projects of national identity from its inception, serving as an advertisement for colonization, as the "first symbol of the United States," 38 as a subject for nineteenth-century attempts at an indigenous literature, as a genealogical focal point for Virginia's blue blood, as America's "first 'ethnic' woman," 39 and, most explicitly in Lindsay's terms, as the founding of an American race. But this myth of our national origins has also always been a troubled and contradictory one. Pocahontas has been presented as the Dark Lady and the naked savage; Liberty and Indian Princess; symbol of devotion and promiscuousness; Christian and heathen; childlike and the mother of America.

These racial and sexual contradictions were the focus of the burlesques of the Indian woman that followed Lindsay's embrace of our new mother. ${ }^{40}$ In literary parodies, from Philip Moeller's "Pokey-or the Beautiful Legend of the Amorous Indian" (1918) to Christopher Ward's The Saga of John Smith (1928), and in the vaudeville halls of New York, the burlesques tell both of a continued obsession with Pocahontas and an increased attention to the aspects of the story that made her a difficult mother for 1920s America. Moeller portrays a Pocahontas motivated entirely by libido, while Ward reveals Pocahontas to be not Indian at all, but instead the best English blood in the New World. Hemingway provides a merciless parody of the obsession with the Indian woman in his novella, The Torrents of Spring (1926). In a chapter entitled, "The Passing of a Great Race and the Making and Marring of Americans," the hero, sexually crippled since the war, is miraculously cured by the sight of the last Indian squaw. The hero leaves the town with her, stripping himself naked as he goes, while the Indian men who follow, gathering up the discarded clothes, shake their heads: "White chief going to get pretty cold."41 All three versions of the joke play on the problems inherent in employing the Indian woman for the making (or, in Hemingway's term, "marring") of Americans, exposing the sexual and racial contradictions in the use of Pocahontas as the source of the American race. As what is essentially a 
tale of miscegenation, the myth was necessarily troubling to the nativist decade which made popular sensations of the Ku Klux Klan, Lothrop Stoddard, and the Immigration Act.

For Crane, the anxieties these writers read into the story provide the terms and justification for his project of remaking Americans in his own image. Crane retraces the American genealogy in the Pocahontas myth in such a way that the nation is no longer born in an act of miscegenation. Crane's Pocahontas, instead of founding our race with the embrace of the white man, here serves to bring together the two men, Powhatan and Smith. In this union of two men the Jamestown colony is rescued, and the spiritual inheritance that constitutes the unique birthright of the American is begun.

In tracing this native culture to its origins, Crane first presents Columbus worrying over his ability to bring back "the word" he has found: "I bring you back Cathay!" 42 We know that of course he is not bringing back word of Cathay or the "Indian emperies" (48), but the word he is bringing back, through this original act of misreading, is Indian. His return mirrors that of America in World War I, bringing back the Indian, and the power of this word has similarly isolated Columbus from the Old World: "I thought of Genoa; and this truth, now proved, / That made me exile in her streets" (48). Columbus is trapped "here between two worlds," for his discovery of the Indian has exiled him from the Old World, while his inability to read the Indian correctly has denied him the New. It is the poet's task to complete this voyage of discovery, "to do a great deal of pioneering myself" $(\mathrm{L}, 305)$, in order to establish the correct relation of the Indian to American identity. It is in "Powhatan's Daughter" that this pioneering voyage takes place.

The epigraph to "Powhatan's Daughter," from William Strachey's contemporary debunking of Pocahontas, presides over what is to follow by reminding us where the wrong reading of Pocahontas has led:

"-Pocahuntus, a well-featured but wanton yong girle . . . of the age of eleven or twelve years, get the boyes forth with her into the market place, and make them wheele, falling on their hands, turning their heels upwards, whom she would followe, and wheele so herself, naked as she was, all the fort over." (53)

Where this heterosexual Pocahontas drives the boys "into the market place," the poem's rereading of Pocahontas provides the guide who 
will lead the poet away from the market, "past the din and slogans of the year" (63). Thus, "Harbor Dawn," the first section of "Powhatan's Daughter," introduces the poet waking up to the noises of the Brooklyn waterfront. As in each of the first three poems of "Powhatan's Daughter," a sound produced by the modern commercial society that has severed the poet from his origins doubles as a bridge that will carry him back to a primal memory: "And if they take your sleep away sometimes / They give it back again" (54). Here, lying in the arms of his lover, the harbor's sounds recall him to a timeless encounter, "in a waking dream," with a first love:

your hands within my hands are deeds;

my tongue upon your throat-singing

arms close; eyes wide, undoubtful

dark

drink the dawn-

a forest shudders in your hair! (56)

And laid out on the page opposite this scene is the motivating question: "with whom?" Although the question allows for the assumption that it is to be Pocahontas herself, in this myth she functions not as the lover but as the intercessor, taking the poet back to the site of that original encounter with her own body as the bridge between the sundered pair. As the prose continues:

Who is the woman with us in the dawn? . . . whose is the flesh our feet have moved upon? ... Like Memory, she is time's truant, shall take you by the hand. ... ( 57,59$)$

"Pocahontas (the continent)," Crane wrote in a letter, "is the common basis of our meeting" (L, 307).

"Van Winkle" takes the first step in answering "with whom?" Here the poet's guide, arriving from another American myth, is he who left his wife to join a community of men in the woods. And over the sound bridge of the "hurdy-gurdy," Rip guides the poet through the process of self-recovery:

The grind-organ says . . Remember, remember

The cinder pile at the end of the backyard

Where we stoned the family of young

Garter snakes under. . . . (60) 
The poet recalls a childhood suppression of desire, figured in the stoning of the snakes in the backyard:

the rapid tongues

That flittered from under the ash heap day After day whenever your stick discovered Some sunning inch of unsuspecting fibreIt flashed back at your thrust, as clean as fire. (60)

Sundering him from access to the original union, this act had been enforced through corporal punishment by the father ("the whip stripped from the lilac tree / One day in spring my father took to me") and religious hypocrisy by the mother ("the Sabbatical, unconscious smile / My mother almost brought me once from church") (60). The biological family is held accountable for the self-violence which divided the poet from his first love. Through the guidance of Rip, the poet imagines the biological family at the root of this repression, so the renouncement of the family which begins here becomes an act of recovery of sexual identity.

With "The River," another intermediary bridge is constructed, here towards a recovery of racial identity. The roar of commercialism and technology, as embodied in the speeding Twentieth Century Limited, leaves in its tracks three black hobos, modern day stand-ins for Rip, "wifeless or runaway." These men form an intermediate identification for the poet to pass through before he can achieve union with the Indian in the next section, as if he must first put on blackface in order to see red.

The hobos are "born pioneers," innocent possessors of an instinctual knowledge of the land, and Crane juxtaposes these men and their myths to the father who had punished the young poet for his desires. By locating the hobos "Behind / My father's cannery works," they can offer a very different set of lessons from the father's commercialism and the father's whip:

Rail-squatters ranged in nomad raillery,

The ancient men-wifeless or runaway

Hobo-trekkers that forever search

An empire wilderness of freight and rails.

Each seemed a child, like me, on a loose perch,

Holding to childhood like some termless play. $(64,66)$ 
These dispossessed men know the land "without name," they know Pocahontas without knowing "the myths of her fathers." As the missing link between modern America and Native America, the hobos know Pocahontas without the ability to recover the power of that bridge: "They know a body under the wide rain." The poet must first experience the land as they do, learn their myths ("Jesus! Oh I remember watermelon days," "There's no place like Booneville though, Buddy . . . -For early trouting" [64]), hum "Deep River," and walk with them a while to learn all they can teach him of the true Pocahontas.

This section engages blacks as stepping-stones back to the pure race of the Indian. Crane referred to the hobos as "psychological ponies" that would "carry the reader across the country and back to the Mississippi," allowing him to "unlatch the door to the pure Indian world which opens out in 'the Dance' section" (L, 303). Identifying the black men as "Grimed tributaries to an ancient flow" (68), the poet charts his progress through their ancillary knowledge towards the river which will carry him finally to the "pure Indian world" of Maquokeeta and "The Dance." Walking on their "backs," the poet empowers his recovery of the Indian for the homosexual American by employing the black as the unassimilable minority. Imagined as a dispossessed, drifting, and dying race, the sacrificed black serves as the poet's vehicle back to the Indian in an especially horrific image:

The River, spreading, flows-and spends your dream.

What are you, lost within this tideless spell?

You are your father's father, and the stream-

A liquid theme that floating niggers swell. (69)

In his effort to establish a genealogical bond that would evade the biological one of father and mother, the poet seems to authorize racist violence in using the bodies of blacks, a race excluded from both Progressivist and nativist constructions of American identity, to propel his course back to the Indian in order that he might truly become his "father's father."

In the first three sections of "Powhatan's Daughter," the poet's "waking dream" (55) of a lost union leads him to travel back over two intermediary bridges: first towards a recovery of sexual identity from the biological family, and then towards a recovery of racial identity through the dispossessed wisdom of an unassimilable race. Having 
defined his voyage in these terms, the poet is now prepared for the reunion of "The Dance."

From the start of "The Dance," we are told that "the swift red flesh" to which the river carries him is not Pocahontas but the "winter king," "her kin, her chieftain lover" $(70,71)$. Pocahontas has been tamed to appear only as land, river, and bridge-the ground upon which the white man and the Indian are reunited. Crane begins by describing a version of the encounter with the original pioneers that had served to divide the two races:

Mythical brows we saw retiring-loth, Disturbed and destined, into denser green.

Greeting they sped us, on the arrow's oath:

Now lie incorrigibly what years between. . . . (70)

But now through the intercession of Pocahontas, to whom the poet prays as Columbus did the Virgin ("O Princess whose brown lap was virgin May"), this distance is negotiated. Through her the poet is able to find the site of the Indian camp, buried deep within the interior of the continent and inaccessible to the traditional pioneer.

I left the village for dogwood. By the canoe

Tugging below the mill-race, I could see

Your hair's keen crescent running. . . . (70)

She guides the poet down the river to its secret core, and she teaches him the Indian's ways: "I learned to catch the trout's moon whisper." After completing his education, Pocahontas leads the poet to that shore which Columbus had earlier vainly bemoaned as the "one shore beyond desire." The acculturated poet can now stride over the landscape like a Whitmanian giant into the hidden interior:

Over how many bluffs, tarns, streams I sped!

-And knew myself within some boding shade:-

Grey tepees tufting the blue knolls ahead,

Smoke swirling through the yellow chestnut glade. . . .

A distant cloud, a thunder-bud-it grew, That blanket of the skies: the padded foot

Within, -I heard it: 'til its rhythm drew,

-Siphoned the black pool from the heart's hot root! (72) 
Arriving finally at the "pure Indian world," the blackface the poet had assumed in order to undertake this backwards voyage is "siphoned" so that the poet can now become the whitest man of all.

The meeting between the white man and Indian chief is staged at the moment when the Indian is engaged in what is at once his ecstasy and his death-throes in a sacrifice to the earth, Pocahontas. The poet initially positions himself as a witness to this the dance, exhorting Maquokeeta to die splendidly:

A cyclone threshes in the turbine crest,

Swooping in eagle feathers down your back;

Know, Maquokeeta, greeting; know death's best;

-Fall, Sachem, strictly as the tamarack!

A birch kneels. All her whistling fingers fly.

The oak grove circles in a crash of leaves;

The long moan of a dance is in the sky.

Dance, Maquokeeta: Pocahontas grieves. . . . (72-73)

But as the poet's commands grow increasingly erotic, the distance remaining between Indian and white man becomes effaced until the poet and Indian can dance as one.

Dance, Maquokeeta! snake that lives before,

That casts his pelt, and lives beyond! Sprout, horn!

Spark, tooth! (73)

The images that describe the dance closely mirror those of the primal union in "Harbor Dawn," identifying the first lover as this Indian man:

And every tendon scurries toward the twangs

Of lightning deltaed down your saber hair.

Now snaps the flint in every tooth; red fangs

And splay of tongues thinly busy the blue air. . . (73)

Maquokeeta emerges as the suppressed snake of "Van Winkle." As the snake "that casts his pelt, and lives beyond," the Indian chief discards his red skin to live on in the white poet. This image is repeated at the dance's end: "like the lizard in the furious noon, / That drops his legs and colors in the sun, / - And laughs, pure serpent" (74). By casting off his Indian race, sacrificing his identity to the white, he allows the poet to be wholly identified with the Indian dance: 
I, too, was liege

To rainbows currying each pulsant bone:

Surpassed the circumstance, danced out the siege!

And buzzard-circled, screamed from the stake;

I could not pick the arrows from my side.

Wrapped in that fire, I saw more escorts wake-

Flickering, sprint up the hill groins like a tide.

In this sacrificial scene, the red man dies that the homosexual poet can be reborn as the true American, and the section ends with Maquokeeta transferring his identity to the poet through a bond of marriage: "We danced, O Brave . . . made our vows." The homosexual poet is sole beneficiary of this identity, he alone returns to tell us, while Pocahontas, the bridge to this reunion, remains "virgin to the last of men" (74).

"The Dance" bridges the two nonprocreative models of genealogy that had been polarized as mutually exclusive terms during the war. By rereading Pocahontas in terms of the union of white man and Indian chief, this act becomes the nation's founding moment, originating the nonbiological inheritance that had attempted to proscribe homosexuality from its machinery. The poem redefines American identity in terms that would make this version of the Pocahontas myth the necessarily correct formula for this transmission of cultural identity. And in this way, Crane's seemingly inconsonant statement that " race' is the principal motivation of "Indiana" " $(\mathrm{L}, 358)$ begins to make important sense. For the section that follows the ecstatic union of "The Dance" reverses the terms it has been defining up to this point in order to follow out the fatal implications of a traditional biological reading of Pocahontas to a conception of an American race.

"Indiana" describes a son leaving his mother for the community of men at sea, while she begs him to remain within the family. This mother's significance, according to Crane, lies in "her succession to the nature-symbolism of Pocahontas" (L, 307). But as this heir to Pocahontas asks the son to embrace the reading of the myth that the poem has rejected, we know the succession is to be read as illegitimate. To expose the barrenness of this false genealogy, the poem reveals the mother's arguments for the demands of the family to be self-defeating. Opening with an account of the son's origins, modern capitalism is immediately correlated to biological birth as the mother recounts the family's disastrous search for gold: 
And bison thunder rends my dreams no more

As once my womb was torn, my boy, when you

Yielded your first cry at the prairie's door. . . .

Your father knew

Then, though we'd buried him behind us, far

Back on the gold trail-then his lost bones stirred. . . . (76)

The violence of biological birth, the destructive drive of greed, and the sundering of the family are all brought together in this account of the son's inception, so that his decision to leave the family for a life at sea becomes a rejection of all these at once.

The mother's tale, told in the attempt to keep her son at home, offers the poem's condemnation of biology:

The long trail back! I huddled in the shade

Of wagon-tenting looked out once and saw

Bent westward, passing on a stumbling jade

A homeless squaw-

Perhaps a halfbreed. On her slender back

She cradled a babe's body, riding without rein.

Her eyes, strange for an Indian, were not black

But sharp with pain

And like twin stars. They seemed to shun the gaze

Of all our silent men - the long team line-

Until she saw me-when their violent haze

Lit with love shine. . . .

I held you up-I suddenly the bolder. . . . (78)

The gold rush and son's birth of the same year have yielded nothing but "barren tears" and a broken family. Returning, the mother sees the modern Indian woman, the other successor to Pocahontas, but one who is now (as she indeed must be) a "halfbreed." Dispossessed, aimless, "riding without rein," this modern Pocahontas is, like the pioneer mother, a victim of the violence and greed that Crane portrays as intrinsic to the traditional reading of the myth and to the biological family itself. So when these two sundered aspects of Pocahontas try to find communion on the wasteland, they can only point to the children who define their condition. The condition of pioneer woman and "half- 
breed" squaw reveals how the wrong reading of Pocahontas has made a notion of a pure race impossible to defend. Crane's statement that "Indiana" is all about race turns out to be exactly right: To be a woman, in the terms of this poem, is necessarily to be a halfbreed and to produce halfbreeds; in this way The Bridge imagines that only through a homosexual genealogy is a pure race possible.

The family is shattered by the "dream called Eldorado" (78); the Indian is degenerated into a halfbreed; and the progress of the nation is brought to a halt on the barren prairie. Homosexuality becomes the way to have an American race, and biology, as figured by these two mothers, is that which defeats it. The son, rejecting the family to become a sailor, is transformed in the following section, "Cutty Sark," into a Melvillian explorer of the "damned white Arctic" who "can't live on land" (83). And the poet's encounter with this sailor will propel him to cross the Bridge towards the Whitmanian manifesto of "Cape Hatteras."

* $* * \quad *$

Both the literary search for an American culture and the politicized defenses of American stock worked to invent a fixed national identity and to protect its boundaries; and both spell out anxious scenarios about procreation in which the failure of biology to reproduce American culture results in its extinction. For the nativists and eugenicists, this anxiety surfaces in the belief that immigrant populations are reproducing ever faster and will soon, through sheer number, define what it means to be American. For the literary defenses of America, most graphically in Williams's In the American Grain (1925), the enemy is located within the impotence of the Puritan businessman and the barrenness of the modern American woman; defending American culture necessitates the recovery of a native passion in what is imagined to be Indian terms. For both literary and political thinkers, the Indian becomes what will rescue us from our mixed inheritance, defining ours as a race apart precisely because the Indian, no longer a symbol of assimilation, has successfully resisted the melting pot mistake, remaining untainted by European blood. As Waldo Frank valorizes the Indian in Our America (1919), he "has preserved his culture admirably. He does not intermarry." This unmixed race reveals in the act of vanishing "the temper of his breeding" as he "withdraws forever farther within 
himself," ${ }^{43}$ so that his buried culture can now provide the untapped potential of our own.

Working out of the terms established by the war years (the period during which Crane began to define both his poetic project and his sexuality), The Bridge seizes upon Pocahontas as a true founding myth of the American culture and, at the same time, a forum for the anxiety over biological reproduction that is evinced by the burlesque, nativist, and modernist texts. Crane employs a burlesque nightmare of Pocahontas in The Bridge to portray the natural end of the traditional reading of the myth. His own interest in the burlesques is revealed by a notebook entry, written while composing "The Dance," listing imaginary titles for burlesque songs on Indian themes. ${ }^{44}$ The poem makes direct use of this tradition in "Three Songs," the antipode to the climax of "The Dance," in which Pocahontas is exposed in full heterosexual regalia, what R. W. B. Lewis calls "the furthest debasement of the feminine ideal." 45

The "Three Songs" describe the inability of achieving the union of "The Dance" with a woman. The first song, "Southern Cross," parades a litany of mythical women from which the poet might choose an object of worship but among which he finds only degenerated versions: "simian Venus, homeless Eve" (98). "Virginia" describes the attempt at a worldly object in the form of an office girl, but high atop the Woolworth building she remains inaccessible to the poet, her desires defined entirely by the workaday world: "rain at seven / Pay-check at eleven/ Keep smiling the boss away" (102).

It is the middle poem in this section, however, which most powerfully enacts the failure of the heterosexual Pocahontas by presenting the barren woman of Williams's nightmare in the artless dance of modern culture. At the "National Winter Garden," the great vaudeville theater for which the poem is named, Crane might well have seen burlesques of Pocahontas, one of the most popular themes of the time. ${ }^{46}$ And it is here the poet comes in search of a modern Pocahontas, while finding in the bawdy dancer on stage only "some cheapest echo of them all" (100). He attempts to transform her into an object for his poetic project, by asking: "And shall we call her whiter than the snow?" But simply in raising the question of race through this modern Pocahontas, the quest defeats itself. The poem graphically displays the impossibility of having race through a heterosexual model of genealogy, as the dancer, artificially tinted "first with ruby, then with emerald sheen," 
is suddenly exposed by the slide projector which had provided her race: "A caught slide shows her sandstone grey between" (100). And when this raceless, grey Pocahontas removes the veil she had so assiduously guarded in "Powhatan's Daughter," exposing her genitalia to the crowd, she reveals something so monstrous that "we flee her spasm through a fleshless door" (100). The poet had come to find a heterosexual model for Pocahontas and discovered only "the burlesque of our lust" (101).

Crane places the heterosexual failures of "Three Songs" in opposition to the experience of the previous section, "Cape Hatteras," in which the ideal of male love is enacted through the poet's claim of Walt Whitman as the homosexual father, engaging the spiritual genealogy empowered by "The Dance." This bond with a homosexual father holds "us in thrall / To that deep wonderment, our native clay," the "red, eternal flesh of Pocahontas" (88). The founding of this genealogy allows the poet to trace his way back to the true Pocahontas as the mother of this transmission, a mother whose "native clay" can only be defended through the enactment of such an inheritance. Women in Crane's myth are transformed into the land so that men can become men; and "Cape Hatteras" goes so far as to sunder the original biological parents:

Adam and Adam's answer in the forest

Left Hesperus mirrored in the lucid pool. (89)

This all-male genealogy, the poem suggests, escapes the fatal narcissism that brought Eve to the pond's edge and evil to the world, for in this Eden the pool in which Milton's Eve revealed her weakness here reflects only the evening star. Whitman embodies this "pure impulse inbred . . . a pact, a new bound / Of living brotherhood!" (93) and the section ends with the engagement of this bond, defying biology (and mortality) to mark a new inheritance: "My hand / in yours, / Walt Whitman - / so-" (95).

Crane's American myth cannot be fully understood without recasting the logic which defined its terms and made such a project both necessary (by the exclusion of homosexuality from the machinery of citizenship) 
and conceivable (by theorizing a nonbiological relationship to the Indian) for the homosexual poet in 1920s America. While it was through poetry and the example of Whitman that he began constituting a voice for his sexuality in his early poems, Crane's ambition to be the American poet of his generation, defining a "new cultural synthesis" for "our America," must be seen as itself an expression of the model of cultural citizenship emerging from the war.

Working out of the terms whereby the vanishing Indian comes to define American culture, Crane can write himself as the American poet for which the age is calling. The ideal transmission of American culture comes to be reimagined as necessarily a homosexual model of reproduction: the modernist poet as the lover of vanishing Indian men, he who most fully is able to imagine the separation of genealogy from procreation and to trace descendence through nonbiological inheritance, the purest genealogy of all. Thus, homosexuality, actively persecuted during World War I in the process of defining American citizenship in terms of a nonbiological relationship to the Indian, becomes here the perfect example of that relationship. As Werner Sollors identifies Lindsay's Pocahontas as an ancestor "who subverts identification by 'blood" descent," 47 so Crane, writing in the decade that burned all bridges behind Lindsay's declaration of Americanization, could embrace Pocahontas one last time in order to write a genealogy for America which fully evades the complications of biological descent.

Describing the anxiety of biology as it haunted the 1920s, Michaels writes, 'Races, obliged to 'breed' their 'best,' seem required to make do with reproduction, and so the white race, a breeding disaster, seems doomed." In response, American modernists searched out the terms which would "replace reproduction with reincarnation," 48 substituting a spiritual identification with vanishing American Indians to evade the necessary failure of biology to produce a defensible pure race. And in terms of this concern with the efficacy of reproduction, Crane's poem becomes perhaps the most successful modernist text of all by founding a notion of race that fully bypasses the body in favor of an incorruptible machinery of cultural transmission.

\section{NOTES}

1. Carl G. Jung, “Your Negroid and Indian Behavior,” Forum 83 (Apr. 1930): 193, 195. 
2. Hart Crane, The Letters of Hart Crane, 1916-1932, ed. Brom Weber (New York, 1952), 124. Hereafter, references will be cited in the body of the text as $L$.

3. Thomas Parkinson, ed., Hart Crane and Yvor Winters: Their Literary Correspondence (Berkeley, 1978), 20.

4. Waldo Frank, The Rediscovery of America: An Introduction to a Philosophy of American Life (1929; reprint, Westport, Conn., 1982), 230.

5. Jung, "Your Negroid and Indian Behavior," 197.

6. The best general study by far of the development of the homosexual project central to Crane's poetry is Thomas E. Yingling, Hart Crane and the Homosexual Text: New Thresholds, New Anatomies (Chicago, 1990).

7. As R. P. Blackmur censored the poem, it "requires of the reader that he supply from outside the poem, and with the help of clues only, the important, controlling part of what we may loosely call the meaning." Allen Tate, himself engaged in the founding of the great literary America, identifies this site "outside the poem" and finds it barren: "If we subtract from Crane's idea its periphery of sensation, we have left only the dead abstraction, the Greatness of America, which is capable of elucidation neither on the logical plane nor in terms of a generally known idea of America . . . Does American culture afford such a subject? It probably does not." (R. P. Blackmur, Language as Gesture [New York, 1980], 301; Allen Tate, "Hart Crane," in Critical Essays on Hart Crane, ed. David R. Clark [Boston, 1982], 119.)

8. Where the poem's engagement with American history is taken account of at all, it is often either dismissed as, in William Pritchard's words, "the least attractive and corniest aspect of The Bridge," or is disavowed as being entirely beside the point, as by John Carlos Rowe, who argues that "the poem itself is an extended attack on the very idea of American history." (William Pritchard, Lives of the Modern Poets [New York, 1980], 253; John Carlos Rowe, "The 'Super-Historical' Sense of Hart Crane's The Bridge," Genre 11 [Winter 1978]: 607.) See also Joseph R. Riddel, "Hart Crane's Poetics of Failure," in Modern American Poetry: Essays in Criticism, ed. Jerome Mazzaro (New York, 1970), 273.

9. "Postwar studies estimated that more than ten thousand Indian men served in the United States and Canadian armies during the war, and fully three-fourths of these were volunteers who did not have to enlist because of their noncitizenship status" (Michael L. Tate, "From Scout to Doughboy: The National Debate over Integrating American Indians into the Military, 1891-1918" Western Historical Quarterly 17 [Oct. 1986]: 430). See also, John C. Ewers, "A Crow Chief's Tribute to the Unknown Soldier," American West 8 (Nov. 1971): 30-33.

10. Widespread authorized experiments and tests were performed on enlisted soldiers during World War I by scientists under Robert M. Yerkes in order to prove the existence of inherent racial difference. Coming out of the war, these studies were used by policy makers and racists to give scientific authority to the growing movement towards immigration restriction in the 1920s. In this study I focus on two of the groups, homosexuals and Indians, whose relationship to America was experimented with and redefined during the war. For an excellent account of the broader history and the shift away from assimilationism, see John Higham, Strangers in the Land: Patterns of American Nativism 1860-1925 (New Brunswick, N.J., 1955); Thomas F. Gossett, Race: The History of an Idea in America (New York, 1965); and Stephen Jay Gould, The Mismeasure of Man (New York, 1981).

11. It should be emphasized that what is being described here are ideological appropriations of Indian identity by white America, a history, as Robert Berkhofer has pointed out, that often moves in very different directions from that of Native Americans themselves and the historical appropriations of their lands and rights by 
white Americans. As Berkhofer writes, "Although the social and cultural attributes of Native Americans influenced the conception of them by Whites, it is ultimately to the history of White values and ideas that we must turn for the basic conceptual categories, classificatory schema, explanatory frameworks, and moral criteria by which past and present Whites perceived, observed, evaluated, and interpreted Native Americans." Following Berkhofer's history of the "centuries-old White effort to understand themselves through understanding Native Americans," I am using the term "Indian" to refer to white America's image of historical Native Americans (Robert F. Berkhofer, Jr., The White Man's Indian: Images of the American Indian from Columbus to the Present [New York, 1978], xvi).

For excellent discussions of the impact of the shift towards anti-assimilationist policies on Native Americans, see Francis Paul Prucha, The Indians in American Society: From the Revolutionary War to the Present (Berkeley, 1985); Frederick E. Hoxie, A Final Promise: The Campaign to Assimilate the Indians, 1880-1920 (Lincoln, Nebr., 1984); Christine Bolt, American Indian Policy and American Reform: Case Studies of the Campaign to Assimilate the American Indians (London, 1987).

12. The best accounts of this debate are found in Tate and in Francis Paul Prucha, The Great Father: The United States Government and the American Indians (Lincoln, Nebr., 1984), 771. Interestingly, Tate tells the story from Ayer's point of view, while Prucha's version focuses entirely on Sells's arguments.

13. Cato Sells, "The 'First Americans' as Loyal Citizens," American Review of Reviews 57 (May 1918): 523.

14. House Committee on Military Affairs, North American Indian Cavalry: $H . R$. 3970, 65th Cong., 25 July 1917, 10.

15. "American Indian Poetry," American Review of Reviews 57 (May 1918): 524.

16. Frank C. Lockward, The Life of Edward E. Ayer (Chicago, 1929), 228.

17. See note 10. In The Melting Pot Mistake (1926), Henry Pratt Fairchild proclaimed, "It seems evident that forces were at work which, if they had not been interrupted by the war, would in a few years have reduced the old immigration almost to zero." (George Harrison Knoles, ed., The Responsibilities of Power: 1900-1929 [New York, 1967], 387-88.)

18. Robert DeC. Ward, "Our New Immigration Policy" (1924), in The Politics of the Nineteen Twenties, ed. John L. Shover (Waltham, Mass., 1970), 127, 133-34. Nativist writers of the period making similar arguments about the perceived failure of the melting pot include Madison Grant, The Passing of the Great Race (New York, 1916); Lothrop Stoddard, The Rising Tide of Color Against White World-Supremacy (New York, 1920); Charles Conant Josey, Race and National Solidarity (New York, 1923); Gino Speranza, Race or Nation: A Conflict of Divided Loyalties (Indianapolis, 1923); Albert Edward Wiggam, The Fruit of the Family Tree (Indianapolis, 1924). Most of these works were popular successes.

19. Lothrop Stoddard, The Rising Tide of Color Against White World-Supremacy (New York, 1920), 5.

20. Larry Wayne Ward, The Motion Picture Goes to War: The U.S. Government's Film Effort During World War I (Ann Arbor, Mich., 1981), 103.

21. Jennings C. Wise, The Red Man in the New World Drama: A Politico-Legal Study with a Pageantry of American Indian History (Washington, D.C., 1931), 524.

22. Walter Benn Michaels, "The Vanishing American," American Literary History 2 (Summer 1990): 231. My understanding of the 1920s is extremely indebted to Michaels's work in general, and to this essay in particular for its explanation of the use of the Indian in the defining of American citizenship during this period.

23. Vachel Lindsay, Selected Poems (New York, 1963), 117. 
24. John Palmer Gavit, American By Choice (New York, 1922), 12.

25. As with my discussion of the Indian, I wish here to make the similar point that while the events here discussed had very real impact upon historical people, what is central to the argument at hand is the way in which the notion of a "homosexual threat" was constructed during the war based on assumptions and characterizations that had little to do with the experiences of the actual men these policies and theories targeted.

26. It is important to note that the notion of the vanishing Indian is a white fantasy, and in actuality the Native American population was beginning a period of growth at this time.

27. Carroll Smith-Rosenberg, Disorderly Conduct: Visions of Gender in Victorian America (New York, 1985), 282.

28. Lawrence R. Murphy, Perverts by Official Order: The Campaign Against Homosexuals by the United States Navy (New York, 1988), 299. My account of the Newport scandal is derived primarily from this work, with additional information and insights from Geoffrey $\mathrm{C}$. Ward, A First-Class Temperament: The Emergence of Franklin Delano Roosevelt (New York, 1989); Jonathan Katz, Gay/Lesbian Almanac (New York, 1983); and George Chauncey, Jr., "Christian Brotherhood or Sexual Perversion?: Homosexual Identities and the Construction of Sexual Boundaries in the World War I Era," in Hidden From History: Reclaiming the Gay and Lesbian Past, ed. Martin Bauml Duberman, et al. (New York, 1989), 249-317.

29. Murphy, Perverts by Official Order, 8.

30. Ibid., 16.

31. Ibid., 163.

32. New York Times, 20 July 1921, 4.

33. This dispersal of information helps justify a narrative whereby Roosevelt's vice squad contributes to the homosexualization of the American consciousness. Only a few years after the release of the report, the press would find it possible to print many details it here found "unprintable." As Jonathan Katz writes, it is after the war that the terms of homosexuality move "out of the narrow world of physicians into the larger world reflected in New York Times news reports, book, film, and play reviews" (Katz, Gay/Lesbian Almanac, 137). There is a sense in which the emergence of the homosexual presence in America was perceived to have been made possible by World War I itself. As the New York Times made the connection, "The situation which the committee investigated arose out of the unusual conditions of wartime, when from 15,000 to 20,000 boys and young men who had enlisted in the Navy were sent to Newport for training" (4).

34. The operation at Newport, while the most widely promulgated campaign, was not an isolated one. In Psychopathology (1920), Dr. Edward Kempf cites his discovery of the phenomenon of "acute homosexual panic" during the war, "panic due to the pressure of uncontrollable perverse sexual cravings." He presents numerous case histories revealing the widespread and systematic confinement of soldiers suspected of homosexuality, writing of one characteristic case, "The present psychosis began two years after his first enlistment in the United States Army. His indifference and 'queer, silly' behavior caused him to be confined in the Post Hospital" (Edward J. Kempf, Psychopathology [St. Louis, Mo., 1920], 493).

35. Murphy, Perverts by Official Order, 284.

36. John Irwin, "Naming Names: Hart Crane's 'Logic of Metaphor,'" Southern Review 11 (Apr. 1975): 289.

37. Philip Young, “The Mother of Us All: Pocahontas Reconsidered," Kenyon Review 24 (Summer 1962): 391-92. 
38. Leslie Fiedler, The Return of the Vanishing American (New York, 1968), 65.

39. Mary Dearborn, Pocahontas's Daughters: Gender and Ethnicity in American Culture (New York, 1986), 5.

40. For a full account of the history of the Pocahontas burlesque, see Werner Sollors, Beyond Ethnicity: Consent and Descent in American Literature (New York, 1986), $131-41$.

41. Ernest Hemingway, The Torrents of Spring: A Romantic Novel in Honor of the Passing of a Great Race (1926; reprint, New York, 1972), 88.

42. All passages from The Bridge are quoted from The Complete Poems and Selected Letters and Prose of Hart Crane, ed. Brom Weber (New York, 1966). Hereafter, citations will be given parenthetically in the text by page number.

43. Waldo Frank, Our America (1919; reprint, New York, 1972), 111, 115.

44. Some examples of Crane's burlesque titles are: "Pipe down, Pocahontas, I'd like to Warm Your Wampum, Who Pokes your Hontas when I'm Gone, Wig Wagging in a Wigwam, I'm Happy in your happy Hunting Ground." See Kenneth A. Lohf, "The Prose Manuscripts of Hart Crane: An Editorial Portfolio," Proof 2 (1972): 4243.

45. R. W. B. Lewis, The Poetry of Hart Crane: A Critical Study (Princeton, N.J., 1967), 343.

46. Paul Giles, Hart Crane: The Contexts of "The Bridge" (Cambridge, 1986), 58.

47. Sollors, Beyond Ethnicity, 79.

48. Walter Benn Michaels, "The Souls of White Folk," in Literature and the Body: Essays on Populations and Persons, ed. Elaine Scarry (Baltimore, 1988), 201, 202. 